\title{
HUBUNGAN KEPATUHAN MENGKONSUMSI TABLET FE (ZAT BESI) DAN ASUPAN MAKANAN DENGAN KEJADIAN KEKURANGAN ENERGI KRONIS (KEK) PADA IBU HAMIL DI KOTA MATARAM TAHUN 2018
}

\author{
Cahaya Indah Lestari \\ Prodi D3 Kebidanan, Universitas Muhammadiyah Mataram, email: cahayaisnaini2011@gmail.com
}

\section{INFO ARTIKEL}

Riwayat Artikel:

Diterima: 06-02-2019

Disetujui: 22-07-2019

\section{Kata Kunci:}

Tablet Fe

Asupan Makanan

Kekurangan Energi

Kronis (KEK)

\section{A. LATAR BELAKANG}

Rencana Pembangunan Kesehatan Jangka Menengah Nasional (RPJMN) pada periode 2015-2019, merupakan Program Indonesia Sehat dengan sasaran peningkatan derajat kesehatan dan status gizi masyarakat melalui upaya kesehatan dan

\begin{abstract}
Abstrak: Kekurangan Energi Kronis (KEK) merupakan masalah gizi yang terjadi pada Ibu hamil. Kekurangan Energi Kronik (KEK) adalah keadaan ibu menderita kekurangan makanan yang berlangsung menahun (kronis) yang mengakibatkan timbulnya gangguan kesehatan. Kurang energi kronis (KEK) pada ibu hamil berdampak terhadap ibu, janin yang dikandung dan bayi yang akan dilahirkan. KEK mempengaruhi pertumbuhan janin, risiko kematian neonatal, risiko terjadinya stunting dan Berat badan lahir rendah (BBLR). Untuk menanggulangi masalah tersebut pemerintahmeluncurkan program Bantuan Operasional Kesehatan (BOK) ke seluruh Puskesmas. Selain Bantuan Operasional Kesehatan (BOK), salah satu program pemerintah adalah pelayanan atau AnteNatal Care (ANC) dengan standar minimal $10 \mathrm{~T}$. Tujuan dari penelitian adalah menganalisis hubungan kepatuhan mengkonsumsi tablet fe (zat besi) dan asupan makanan dengan kejadian kekurangan energi kronis (KEK) pada ibu hamil di Kota Mataram Tahun 2018. Jenis penelitian adalah kuantitatif dengan pendekatan waktu cross-sectional. Populasi dalam penelitian ini adalah semua ibu hamil dengan kehamilan normal yang ada di Puskesmas Wilayah Kota Mataram pada bulan Agustus 2018 sebanyak 1466 orang. Pengambilan tempat dan sampel dalam penelitian dengan teknik probability sampling. Hasil uji statistik bivariat dengan menggunakan chi squre menunjukkan bahwa nilai sig $=0.000(<0.05)$ dengan nilai OR 5.067 artinya ibu hamil yang mempunyai asupan makanan yang sesuai akan 5.067 kali lebih besar untuk mengurangi kejadian kekurangan energi kronis. Jika asupan makanan sesuai maka perpeluang mengurangi kejadian kekurangan energy kronis. Bidan diharapkan dapat meningkatkan kualitas pelayanan ANC terutama dalam konseling mengenai tablet fe dan nutrisi ibu hamil.
\end{abstract}

\begin{abstract}
Chronic Energy Deficiency (CED) is a nutritional problem that occurs in pregnant women. Chronic Energy Deficiency (CED) is the condition of mothers who are suffering from chronic food shortages for years which leads to health problems. Chronic energy deficiency (CED) in pregnant women has an impact on the motherand the fetus that will be born. CED affects the fetal growth, risk of neonatal death, risk of stunting and Low Birth Weight (LBW). To overcome this problem, the government has launched a Health Operational Assistance (HOA) program for all primary health centers. In addition to Health Operational Assistance (HOA), one of the government programs is service or Antenatal Care (ANC) with a minimum standard of $10 \mathrm{~T}$. The purpose of the study was to analyze the relationship between consuming iron tablets and food intake and the occurrence of Chronic Energy Deficiency (CED) in pregnant women at Mataram city in 2018. The type of research is quantitative with a cross-sectional time approach. The population in this study was all pregnant women with normal pregnancies in Primary Health Center of the Mataram City in August 2018 which was 1,466 people. The place and samples in this research were taken through probability sampling technique. The results of the bivariate statistical test using chi square indicated that the sig value $=0.000(<0.05)$ with a value of OR 5.067. It means that pregnant women who had an appropriate food intake would be 5,067 times greater to reduce the incidence of chronic energy deficiency. If food intake is appropriate, the opportunity to reduce the incidence of chronic energy deficiency is bigger. Midwives are expected to improve the quality of ANC services, especially in counseling on taking Fe tablets and nutrition for pregnant women.
\end{abstract}

\footnotetext{
$--------->--------$
}

pemberdayaan masyarakat yang didukung dengan perlindungan finansial dan pemerataan pelayanan kesehatan. Adapun termasuk didalamnya peningkatan kesehatan dan status gizi ibu dan anak (Kemenkes RI, 2015). Kesehatan ibu adalah persoalan utama pembangunan di Indonesia. Namun faktanya, di antara banyak target pencapaian Sustainable Development 
Goals di Indonesia, target kesehatan ibu masih jauh tertinggal dan perlu perhatian khusus.

Berdasarkan SDKI 2012 angka kematian ibu di Indonesia sebesar 359 per 100.000 kelahiran hidup. Sedangkan angka kematian ibu di NTB tahun 2012 sebesar 251 per 100.00o kelahiran hidup. Berdasarkan laporan kabupaten/kota, jumlah kasus kematian ibu di Provinsi NTB selama tahun 2016 adalah 92 kasus, menurun dibandingkan tahun 2015 dengan 95 kasus.

Kekurangan Energi Kronis (KEK) merupakan masalah gizi yang terjadi pada Ibu hamil. Kekurangan Energi Kronik (KEK) adalah keadaan ibu menderita kekurangan makanan yang berlangsung menahun (kronis) yang mengakibatkan timbulnya gangguan kesehatan (Depkes, 2002).

Prevalensi ibu hamil yang mengalami KEK di Indonesia sebesar 23.4\% (Kemenkes, 2013), sedangkan di Provinsi NTB sebesar 26,7. Data Pemantauan Status Gizi (2017) mencatat ibu hamil resiko mengalami Kekurangan Energi Kronis (KEK)di Nusa Tenggara Barat (NTB) adalah $17.40 \%$. Capaian tersebut tidak sesuai dengan target yang diharapkan yaitu tidak lebih dari 15,5\%. Berdasarkan data Dinas Kesehatan Kota Mataram (2016), rata-rata prevalensi ibu hamil Kekurangan Energi Kronis (KEK) di Kota Mataram yaitu $6.09 \%$ mengalami peningkatan menjadi $13.3 \%$ pada tahun 2017. Pada ibu, KEK mempengaruhi produktivitas (Shaheen \& Lindholm, 2006), meningkatkan terjadi kematian dan peningkatan angka kesakitan seperti anemia, pendarahan pasca melahirkan.

Terdapat berbagai macam faktor penyebab KEK, salah satu penyebabnya adalah konsumsi makan yang tidak cukup mengandung energi dan protein atau adanya gangguan kesehatan (Soekirman, 2000). Selama kehamilan diperlukan tambahan energi ekstra sebesar 340-450 kalori setiap hari pada trimester II dan III (Bendich, 2005). Oleh karena itu, kekurangan zat gizi tertentu dan dibiarkan berlarut larut saat hamil dapat menyebabkan ibu hamil yang sebelumnya tidak KEK tidak mustahil akan mengalami KEK dan yang sudah KEK justru akan menimbulkan bahaya yang lebih besar (Ausa et al., 2013).

KekuranganEnergi Kronis(KEK) akan memberikan dampak pada janin, ibu dan bayi. Dampak bagi ibu antara lain anemia, perdarahan, berat badan ibu tidak bertambah secara normal, dan terkena penyakit infeksi, sedangkan dampak pada pada janin yaitu dapat mengakibatkan terjadi kematian janin (keguguran) pada trimester I, dapat mengganggu tumbuh kembang janin pada trimester II dan dapat menyebabkan terjadinya persalinan prematur pada trimester III (Dikes Provinsi NTB, 2016).

Untuk menanggulangi masalah tersebut pemerintah meluncurkan program Bantuan Operasional Kesehatan (BOK) ke seluruh
Puskesmasuntuk meningkatkan upaya kesehatan promotif dan preventif (Wirjatmadi B, 2014). Selain Bantuan Operasional Kesehatan (BOK), salah satu program pemerintah adalah pelayanan atau Ante Natal Care (ANC) dengan standar minimal $10 \mathrm{~T}$. Pelayanan antenatal terkait gizi yang wajib dilakukan adalah penimbangan berat badan, pengukuran tinggi badan, pengukuran Lingkar Lengan Atas, pemberian tablet tambah darah serta penyuluhan dan konseling gizi. Akan tetapi dengan adanya program-program yang dilakukan pemerintah provinsi NTB, kejadian Kekurangan Energi Kronis (KEK) pada ibu hamil masih tinggi.

Berdasarkan uraian dari latar belakang tersebut, penulis tertarik untuk melakukan penelitian dengan judul " Hubungan kepatuhan mengkonsumsi tablet fe ( zat besi ) dan asupan makanan dengan kejadian kekurangan energi kronis (KEK) pada ibu hamil di Kota Mataram Tahun 2018".

\section{B. METODE PENELITIAN}

Jenis penelitian adalah kuantitatif. Desain penelitian yang digunakan dalam penelitian ini adalah deskriptif, penelitian deskriptif adalah suatu penelitian yang dilakukan untuk mendeskripsikan atau menggambarkan suatu fenomena yang terjadi dalam masyarakat. Penelitian ini menggunakan pendekatan waktu secara cross sectional dimana variabel diambildan diteliti dalam kurun waktu yang sama (Notoatmodjo, 2012).

Populasi seluruh ibu dengan kehamilan normal yang ada di Puskesmas Wilayah Kota Mataram pada bulan September-Oktober tahun 2018 sebanyak 1466 orang. Variabel dalam penelitian ini adalah konsumsi tablet tambah darah $(\mathrm{Fe})$ dan asupan makanan dan variabel terikat adalah kejadian kekurangan energi kronis (KEK). Teknik pengambilan sampel dengan teknik Simple Random Sampling dan menggunakan rumus Slovin sehingga jumlah sampel sebanyak 399 responden. Intrumen dalam penelitian ini menggunakan Kuisioner MMAS-8 dan food frequency questioner (FFQ). Uji bavariat dalam penelitian ini menggunakan chi square test. Sedangkan untuk uji multivariat menggunakan uji regresi logistik berganda.

\section{HASIL DAN PEMBAHASAN}

\section{Analisis Univariat}

TABEL 1

Distribusi Frekuensi Analisis Univariat

\begin{tabular}{cclcc}
\hline No & Variabel & Kategori & $\mathrm{n}$ & $(\%)$ \\
\hline 1. & Kepatuhan & Tinggi & 179 & 44.9 \\
& & Rendah & 220 & 55.1 \\
2. & \multirow{2}{*}{ Asupan Makanan } & Sesuai & 237 & 59.4 \\
& & Tidak sesuai & 162 & 40.6 \\
3. & \multirow{2}{*}{ Kejadian KEK } & Tidak KEK & 363 & 91.0 \\
& & KEK & 36 & 9.0 \\
\hline
\end{tabular}

Sumber : Data Primer 2018 
Berdasarkan tabel diatas, didapatkan hasil bahwa sebagian besar ibu hamil memiliki tingkat kepatuhan mengkonsumsi tablet $\mathrm{Fe}$ pada kategori kepatuhan rendah yaitu sebanyak 220 (55.1\%) sedangkan terendah yaitu pada kategori kepatuhan tinggi sebanyak 179 (44.9\%). Sebagian ibu hamil memiliki asupan makanan pada kategori sesuai yaitu sebanyak 237 (59.4\%) sedangkan terendah yaitu pada kategori tidak sesuai sebanyak 162 (40.6). Kejadian kekurangan energi kronis pada ibu hamil sebagian besar tidak mengalami kekurangan energi kronis (KEK) yaitu sebanyak 363 (91.0\%) sedangkan ibu hamil yang mengalami kejadian kekurangan energi kronis (KEK) yaitu sebanyak 36 (9.0\%).

\section{Analisis Bivariat}

TABEL 2

Analisis dengan menggunakan uji chi square

\begin{tabular}{|c|c|c|c|c|c|c|c|c|c|c|}
\hline \multirow[b]{2}{*}{$\begin{array}{l}\mathrm{N} \\
\mathrm{O}\end{array}$} & \multirow{2}{*}{$\begin{array}{l}\text { Var } \\
\text { iabe }\end{array}$} & \multirow[b]{2}{*}{ Kategori } & \multicolumn{2}{|r|}{ KEK } & \multicolumn{2}{|c|}{ Tidak KEK } & \multicolumn{2}{|c|}{ Total } & \multirow{2}{*}{$\begin{array}{c}P \\
\text { value }\end{array}$} & \multirow[b]{2}{*}{ OR } \\
\hline & & & $\mathrm{F}$ & $\%$ & $\mathrm{~F}$ & $\%$ & $\mathrm{~N}$ & $\%$ & & \\
\hline \multirow[t]{3}{*}{1.} & Kep & Tinggi & & & & & & & 0.00 & 4.553 \\
\hline & $\begin{array}{l}\text { atu } \\
\text { han }\end{array}$ & & 6 & 16.7 & 173 & $47 \cdot 7$ & 179 & 44.9 & o & $\begin{array}{l}(1.850- \\
11.202)\end{array}$ \\
\hline & & Rendah & 30 & 83.3 & 190 & 52.3 & 220 & 55.1 & & \\
\hline \multirow[t]{4}{*}{2.} & $\begin{array}{l}\text { Asu } \\
\text { pan }\end{array}$ & Ses & & & & & & & $\begin{array}{l}0.00 \\
0\end{array}$ & $\begin{array}{c}5.067 \\
(2.314-\end{array}$ \\
\hline & $\mathrm{Ma}$ & & 9 & 25.0 & 228 & 62.8 & 237 & 59.4 & & 11.095 \\
\hline & $\begin{array}{l}\text { kan } \\
\text { an }\end{array}$ & & & & & & & & & \\
\hline & & $\begin{array}{l}\text { Tidak } \\
\text { sesuai }\end{array}$ & 27 & 75.0 & 135 & 40.6 & 162 & 40.6 & & \\
\hline \multirow[t]{2}{*}{3 . } & $\begin{array}{l}\text { Um } \\
\text { ur }\end{array}$ & Berisiko & 10 & 27.8 & 44 & 12.1 & 54 & 13.5 & $\begin{array}{l}0.00 \\
9\end{array}$ & $\begin{array}{c}2.788 \\
(1.260-\end{array}$ \\
\hline & & $\begin{array}{l}\text { Tidak } \\
\text { berisiko }\end{array}$ & 26 & 72.2 & 319 & 87.9 & 345 & 86.5 & & 6.172) \\
\hline \multirow[t]{2}{*}{4.} & $\begin{array}{l}\text { Par } \\
\text { itas }\end{array}$ & Berisiko & 18 & 50.0 & 139 & 38.3 & 157 & 39.3 & 0.170 & $\begin{array}{c}1.612 \\
\text { (0.811- }\end{array}$ \\
\hline & & $\begin{array}{l}\text { Tidak } \\
\text { Berisio }\end{array}$ & ${ }^{1} 8$ & $\begin{array}{r}50 . \\
0\end{array}$ & 224 & $\begin{array}{r}61 . \\
7\end{array}$ & $\begin{array}{r}24 \\
2\end{array}$ & $\begin{array}{r}60 . \\
7\end{array}$ & & 3.202 \\
\hline
\end{tabular}

Sumber : Data Primer 2018

Berdasarkan tabel diatas dapat diinterprestasikan bahwa dari empat variabel, asupan makanan merupakan variabel dengan nilai hubungan kekurangan energi kronis paling tinggi dimana nilai OR sebesar 5.067 yang dapat diinterpretasikan ibu hamil yang memiliki asupan makanan yang sesuai akan 5.067 kali lebih besar untuk mengurangi kekurangan energi kronis. Sedangkan secara statistik pada paritas tidak memiliki hubungan dengan kejadian kekurangan energi kronis, hal ini dapat dilihat dari nilai $p$ value 0.170 atau nilai signifikasinya $0.170(>0.05)$ akan tetapi tetap berpeluang untuk terjadinya kekurangan energi kronis sebesar 1.612 yang dapat dilihat dari nilai OR.

Hasil penelitian hubungan tingkat kepatuhan mengkonsumsi fe (zat besi) dengan Kekurangan Energi Kronis pada Ibu Hamil di Puskesmas Wilayah Kota Mataram dengan jumlah responden yang diteliti sebanyak 399 responden, dengan uji Chi Square di dapatkan nilai signifikan ( $p$ value) adalah 0.000 $(p<0.05)$ dengan nilai 4.553 yang dapat diinterpretasikan ibu hamil yang memiliki kepatuhan tinggi akan 4.553 kali lebih besar untuk mengurangi kekurangan energi kronis. Dalam hal ini kejadian KEK pada ibu hamil tidak saja dipengaruhi oleh tingkat konsumsi Fe saja melainkan juga riwayat status gizi sebelum hamil, adanya riwayat penyakit kronis dan lain-lain karena biasanya pada ibu hamil terjadi peningkatan nafsu makan sehingga dapat mencegah terjadinya KEK. (Mardiatun, dkk, 2015).

Hal ini dapat juga dipengaruhi oleh beberapa hal seperti karakteristik latar belakang pendidikan responden yang menunjukkan bahwa dari data yang didapat jumlah pendidikan responden terbanyak yaitu pada tingkat pendidikan tinggi sebanyak 224 responden $(56,1 \%)$ dimana hal ini sejalan dengan pendapat Notoatmodjo (2007), yang mengatakan pendidikan dalam arti formal sebenarnya adalah suatu proses memberikan pengetahuan kepada sasaran pendidik guna mencapai perubahan tingkah laku. Pengetahuan merupakan salah satu faktor penting untuk membentuk suatu sikap yang utuh dalam kepatuhan mengkonsumsi tablet Fe, dimana semakin baik pengetahuan ibu hamil mengenai pentingnya zat besi dan akibat yang ditimbulkan apabila kekurangan zat besi dalam kehamilan akan cenderung membentuk sikap yang positif terhadap kepatuhan sehingga timbul tindakan patuh dalam mengkonsumsi tablet Fe. Dalam penelitian ini adapun karakteristik responden yang mungkin dapat mempengaruhi tingkat kepatuhan dalam mengkonsumsi tablet Fe yaitu paritas dimana dari hasil penelitian ini dapatkan hasil jumlah terbanyak pada kategori tidak berisiko sebanyak 242 responden (60.7\%), dimana sejalan dengan penelitian Zulkiflli dan Eva (2014) yang menyatakan ibu yang pernah melahirkan lebih mempunyai pengalaman tentang kehamilan sebelumnya, sehingga dari pengalaman terdahulu kembali dilakukan agar menjaga kesehatan kehamilannya saat ini.

Keadaan gizi kurang terjadi karena tubuh kekurangan salah satu atau beberapa jenis zat gizi yang dibutuhkan. Beberapa hal yang dapat menyebabkan tubuh kekurangan zat gizi tersebut antara lain, jumlah zat gizi yang dikonsumsi kurang, mutunya rendah atau keduanya. Selain itu zat gizi yang dibutuhkan juga mungkin gagal untuk di serap dan di gunakan tubuh. Kenaikan volume darah selama kehamilan akan meningkatkan kebutuhan $\mathrm{Fe}$ atau zat Besi (Supariasa, 2012) Kebutuhan ibu hamil terhadap energi, vitamin maupun mineral meningkat sesuai dengan perubahan fisiologis ibu terutama pada akhir trimester kedua di mana terjadi proses hemodelusi yang menyebabkan terjadinya peningkatan volume darah dan mempengaruhi konsentrasi hemoglobin darah. Pada keadaan normal hal tersebut dapat diatasi dengan pemberian tablet besi, akan tetapi pada keadaan gizi kurang bukan saja membutuhkan suplemen energi juga membutuhkan suplemen vitamin dan zat besi 
(Supariasa, 2012). Kebutuhan yang meningkat pada masa kehamilan, rendahnya asupan protein hewani, kekurangan vitamin $\mathrm{c}$ dan meningkatnya konsumsi minuman mengandung kafein yang dapat menyebabkan rendahnya penyerapan zat besi di dalam tubuh walaupun ibu hamil mengonsumsi Fe dalam jumlah yang memadai.

Penelitian ini sejalan dengan penelitian oleh Mardiatun, dkk (2015), tentang Hubungan Riwayat Ante Natal Care (ANC dan Tingkat Konsumsi Fe (Zat Besi) dengan Kejadian KEK Ibu Hamil di Provinsi Nusa Tenggara Barat dan di Daerah Istimewa Jogyakarta. Dimana ada hubungan yang signifikan antara Tingkat Kepatuhan Konsumsi Fe (zat besi) dengan kejadian Kurang Energi Kronis pada ibu hamil. Begitu juga dengan penelitian lain yang sejalan dengan penelitian ini yaitu penelitian yang dilakukan oleh Vita Kartika Mahirawati (2014) tentang faktor-faktor yang berhubungan dengan Kekurangan Energi Kronis (KEK) pada Ibu Hamil di Kecamatan Kamoning dan Tambelangan, Jawa Timur, dimana konsumsi pil zat besi merupakan salah satu faktor yang mempengaruhi kejadian kurang energi protein kronis. Dimana pada penelitian ini jumlah persentasi ibu yang mengalami kurang energi protein lebih cenderung tidak patuh dalam mengkonsumsi tablet Fe, selain itu KEK bisa saja terjadi, karena penyerapan pil besi di dalam tubuh dapat dihambat oleh senyawa fitat dan janin yang ada di dalam makanan atau minuman yang dikonsumsi oleh ibu hamil.

Proses Fe untuk menjadi hemoglobin adalah melalui perubahan Ferro menjadi Ferri. Hb mengikat oksigen menjadi oksihemoglobin. Perpaduan oksigen dan glukosa akan menghasilkan ATP (Adenosin Trifosfat) sebagai energi yang beredar. Apabila asupan Fe menurun akan menyebabkan hemoglobin juga akan menurun sehingga ikatan oksigen akan menurun dan ATP yang dihasilkan lebih sedikit. Ibu hamil dan bayi membutuhkan ATP atau energi yang tinggi untuk proses metabolisme maupun untuk pertumbuhan, apabila tidak tersedia maka tubuh akan menggunakan cadangan makanan melalui proses katabolisme dan apabila berlangsung lama akan menyebabkan KEK (Guyton, 2002). Jadi, Asupan zat besi yang kurang ditambah kondisi kehamilan akan meningkatkan metabolisme dan kebutuhan nutrisi pada ibu dan bayi apabila tidak terpenuhi akan meningkatkan risiko kejadian KEK.

Hasil penelitian menunjukkan hubungan asupan makanan dengan kekurangan energi kronis pada ibu hamil di Kota Mataram, dengan Uji Chi Square di dapatkan nilai signifikan ( $p$ value) adalah 0.000 $(p<0.05)$ dengan nilai OR 5.067 yang dapat diinterpretasikan ibu hamil yang memiliki asupan makanan yang sesuai akan 5.067 kali lebih besar untuk mengurangi kekurangan energi kronis. Faktor yang dapat mempengaruhi terjadinya kekurangan energi kronis atau gizi kurang pada ibu hamil adalah asupan makanan yang kurang sebelum dan selama kehamilan. Ibu hamil yang mengkonsumsi makanan dengan jumlah kalori dibawah kecukupan yang dianjurkan dalam jangka waktu lama akan beresiko KEK, yang pada akhirnya dapat melahirkan bayi BBLR. Dalam hal ini dapat dipengaruhi oleh karakteristik pekerjaan responden dimana jumlah terbanyak pada kategori tidak bekerja sebanyak 269 (67,4\%), dimana ibu yang tidak bekerja tidak memiliki akses informasi yang banyak karena sedikitnya waktu dan beban kerja yang di kerjakan sehari-hari sangat banyak seperti harus mengerjakan pekerjaan rumah sendiri, seperti mengurus rumah, mengurus anak dan suami, sehingga beban kerja yang dilakukan oleh ibu hamil sangat mempengaruhi kebutuhan gizi yang dikonsumsi (Arisman, 2010).

Selama masa kehamilan kebutuhan zat gizi yang diperlukan untuk metabolisme tubuh baik pada ibu dan janin dalam kandungan meningkat. Oleh karena itu pada masa kehamilan asupan zat gizi yang diperlukan juga meningkat, untuk pertumbuhan dan perkembangan janin juga pertambahan besarnya organ kandungan, perubahan komposisi dan metabolisme tubuh ibu dan janin. Ibu hamil yang mengalami kekurangan asupan zat gizi dan berstatus gizi buruk maka mempunyai peluang besar untuk melahirkan bayi dengan berat badan lahir rendah (BBLR) (Mahirawati, 2014).

Penelitian lain yang sejalan dengan hasil penelitian yaitu penelitian oleh Gotri, Laksmi, dan Ronny (2016), tentang hubungan sosial ekonomi dan asupan zat gizi dengan Kejadian Kurang Energi Kronik pada Ibu Hamil di Wilayah Puskesmas Sei Jang Kecamatan Bukit Bestari Kota Tanjung Pinang, dimana terdapat hubungan yang signifikan antara asupan zat gizi dengan kejadian kurang energi kronik. Seseorang mengalami kekurangan gizi khususnya asupan protein kurang maka akan memiliki peluang lebih besar untuk mengalami KEK. Hal ini sejalan dengan pesan Gizi Seimbang, jika asupan protein cukup maka status gizi akan baik termasuk ukuran lingkar lengan atas (LILA). Secara teoritis asupan protein berhubungan dengan ukuran lingkar lengan atas, jika asupan protein cukup, maka ia akan berfungsi sebagai energi alternatif terakhir setelah karbohidrat dan lemak terpakai karena protein sebagai multi fungsi yaitu dapat memelihara jaringan tubuh dan serta meningkatkan pertumbuhan (Gotri, Laksmi dan Ronny, 2016).

Sesuai masa kehamilan, kebutuhan gizi meningkat untuk kebutuhan metabolisme ibu hamil itu sendiri dan juga untuk pertumbuhan janin. Metabolisme yang terjadi selama kehamilan yaitu perubahan keseimbangan hormonal. Sehingga dengan kata lain, distribusi zat gizi dalam tubuh selama kehamilan cenderung digunakan untuk pertumbuhan janin dan metabolisme ibu hamil (Moehji, 2003). Asupan 
makanan yang rendah akan berdampak pada status gizi. Kurangnya asupan makanan berpengaruh pada ketersediaan zat gizi lain seperti karbohidrat, protein dan lemak merupakan sumber energi alternatif. Apabila tubuh kekurangan energi maka karbohidrat, protein atau lemak akan mengalami perubahan yang menjadi sumber energi. Sehingga fungsi utama dari ketiga zat tersebut akan menurun. Apabila berlangsung dalam waktu lama, akan terjadi perubahan berat badan dan kerusakan jaringan tubuh (Novika, Nuryanidan Yanti, 2018).

Berdasarkan hasil penelitian bahwa adanya hubungan antara asupan makanan dengan KEK, hal ini juga masih berkaitan data karakteristik responden yang terbilang banyak tidak bekerja yaitu sebanyak 269 responden. Dimana hal ini didukung dengan penelitian yang dilakukan oleh Gotri, Laksmi dan Ronny (2016) yang meneliti tentang hubungan sosial ekonomi dengan kejadian KEK yaitu pendapatan keluarga yang terbatas mempengaruhi kondisi suatu keluarga termasuk status kesehatan keluarga dari seluruh anggota keluarga salah satunya yaitu dalam pemenuhan kebutuhan asupan makanan yang memiliki nilai gizi yang cukup.

\section{Hasil Uji Multivariat}

\section{TABEL 3}

Hasil Analisis Regresi Logistik Berganda Antar Variabel

\begin{tabular}{|c|c|c|c|c|}
\hline \multirow{2}{*}{$\begin{array}{c}\text { Variabe } \\
1\end{array}$} & \multicolumn{2}{|c|}{ Model I } & \multicolumn{2}{|r|}{ Model II } \\
\hline & $\begin{array}{c}P \\
\text { value }\end{array}$ & OR & $\begin{array}{c}P \\
\text { value }\end{array}$ & OR \\
\hline Umur & 0.11 & $\begin{array}{c}3.088 \\
(1.293- \\
7.376)\end{array}$ & 0.18 & $\begin{array}{c}2.824 \\
(1.196-6.667)\end{array}$ \\
\hline Paritas & 0.148 & $\begin{array}{c}1.723 \\
(0.824- \\
3.602)\end{array}$ & & \\
\hline $\begin{array}{c}\text { Kepatu } \\
\text { han }\end{array}$ & 0.003 & $\begin{array}{c}4.152 \\
1.640- \\
10.512)\end{array}$ & 0.002 & $\begin{array}{c}4.260 \\
(1.693-10.720)\end{array}$ \\
\hline $\begin{array}{c}\text { Asupan } \\
\mathbf{R}^{\mathbf{2}} \\
\end{array}$ & 0.000 & $\begin{array}{c}4 \cdot 317 \\
\left(1.933^{-9642)}\right. \\
\mathbf{0 , 1 9 9}\end{array}$ & 0.000 & $\begin{array}{c}4.321 \\
(1.940-9.622) \\
\mathbf{0 , 1 8 9}\end{array}$ \\
\hline
\end{tabular}

Sumber : Data Primer 2018

Berdasarkan tabel diatas untuk melihat hubungan variabel bebas (Kepatuhan mengkonsumsi tablet fe dan asupan makanan) dan variabel pengganggu (umur dan paritas) tentang variabel terikat (kekurangan energi kronik). Analisis regresi yang digunakan dengan menginginkan permodelan dengan metode backwad LR. Pada permodelan ini akan mengeluarkan variabel yang mempunyai nilai $p$ value yang paling besar secara otomatis akan sampai didapatkan permodelan yang tepat.

Analisis multivariat didapatkan variabel yang paling dominan berpengaruh tentang kekurangan energi kronis adalah asupan makanan. Dimana asupan makanan ibu hamil memiliki kekuatan yang paling besar dibandingkan dengan yang lain yakni sebesar OR 4.321. Pada penelitian ini yang menjadi patokan juga adalah nilai $\mathrm{R}^{2}$ dimana nilai $\mathrm{R}^{2}$ yang dibaca adalah pada model II 0,189 karena analisis regresi adalah untuk mengestimasi fungsi kuadrat terkecil (R2). Nilai R2 pada model II adalah 0,189 yang berarti bahwa variabel umur, kepatuhan mengkonsumsi tablet fe dan asupan makanan berpengaruh $18 \%$ dalam kejadian kekurangan energi kronis.

\section{SIMPULAN DAN SARAN}

Berdasarkan hasil penelitian dan pembahasan maka dapat ditarik beberapa Simpulan sebagai berikut:

1. Terdapat hubungan yang bermakna antara asupan makanan dengan kekurangan energi kronis pada ibu hamil di Puskesmas Wilayah Kota Mataram Tahun 2018 dimana nilai $p$ value $0.000(p<0.05)$ dengan nilai OR 5.067 yang dapat diinterpretasikan ibu hamil yang memiliki asupan makanan yang sesuai akan 5.067 kali lebih besar untuk mengurangi kejadian kekurangan energi kronis.

2. Variabel dominan yang memiliki hubungan dengan kejadian kekurangan energi kronis pada ibu hamil di Puskesmas Wilayah Kota Mataram Tahun 2018 yaitu asupan makanan memiliki kekuatan yang paling besar untuk mengurangi kejadian kekurangan energi kronis dibandingkan dengan yang lain yakni sebesar OR 4.321 lebih besar dibandingkan nilai OR umur dan kepatuhan mengkonsumsi tablet fe.

Saran dalam penelitian ini adalah tenaga kesehatan khusunya bidan meningkatkan komunikasi serta edukasi kepada ibu hamil mengenai cara mencegah kejadian kekurangan energi kronis.

\section{UCAPAN TERIMA KASIH}

Tim penulis mengucapkan terima kasih kepada LPPM UM Mataram yang telah mendanai penelitian ini.

\section{DAFTAR RUJUKAN}

[1] Arisman. (2010). Gizi dalam Daur Kehidupan: Buku Ajar Ilmu Gizi. Edisi 2. Jakarta: EGC.

[2] Ausa et al. (2013). Hubungan Pola Makan dan Status Sosial Ekonomi dengan Kejadian KEK pada Ibu Hamil di Kabupaten Gowa. Tesis. Makassar: Universitas Hasanuddin.

[3] Badan Pusat Statistik. (2013). Survei Demografi dan Kesehatan Indonesia (SDKI) 2012. Jakarta : SDKI 2012.

[4] Bendich, A dan R.J. Deckelbaum. (2005). Preventive Nutrition: The Comprehensive Guide for Health Professionals Edisi 3. New Jersey : Humana Press.

[5] Depkes RI. (2002). Pedoman Penanggulangan Ibu Hamil Kekurangan Energi Kronis. Direktorat Pembinaan Kesehatan Masyarakat. Jakarta: Depkes RI.

[6] Dikes Provinsi NTB. Profil Kesehatan Provinsi Nusa Tenggara Barat Tahun 2016. Mataram; 2017.

[7] Dinas Kesehatan Kota Mataram. (2017). Profil Kesehatan Kota Mataram Tahun 2016. Mataram: Dikes Kota Mataram.

[8] Fitrianingsih. (2014). Hubungan Pola Makan Dan Status Sosial Ekonomi Dengan Kejadian Kekurangan Energi Kronik (KEK) Pada Ibu Hamil Di Puskesmas TompobuluAbupaten Gowa Tahun 2014. Tesis. Makassar Universitas Hasanuddin.

[9] Gotri S., Widajanti, Laksmi, \&Aruben, Ronny. (2016). Hubungan Sosial Ekonomi dan Asupan Zat Gizi dengan Kejadian Kurang Energi Kronik (KEK) Pada Ibu Hamil di 
Wilayah Puskesmas Sei Jang Kecamatan Bukit Bestari Kota Tanjung Pinang Tahun 2016. Jurnal Kesehatan Masyarakat, Volume 5, No 3, Juli 2017: 2356-3346.

[10] Guyton A.C.\& Hall J.E. (2008). Buku Ajar Fisiologi Kedokteran Edisi 11. Jakarta: EGC.

[11] Hermawan, W. (2006). Faktor-faktor yang Berpengaruh terhadap Resiko Kurang Energi Kronis (KEK) pada Ibu Hamil di Kecamatan Cimalaka Kabupaten Sumedang. Skripsi.

[12] Kemenkes RI. (2015). Pedoman Penanggulangan Kurang Energi Kronik (KEK) pada Ibu Hamil. Jakarta: Kemenkes RI.

[13] Mahirawati, Vita Kartika. (2014). Faktor-Faktor Yang Berhubungan dengan Kekurangan Energi Kronik (KEK) pada Ibu Hamil di Kecamatan Kamoning dan Tambelangan, Kapupaten Sampan, Jawa Timur. Buletin Penelitian Sistem Kesehatan - Vol. 17 No. 2 April 2014: 193-202.

[14] Mardiatun, Yani, Purnama, Zulkifli, \& Ristrini. (2013). The Relationship of antenatal Care History and Level of Iron Consumption with Incidence of Malnutrition at Pregnant Women in West Nusa Tenggara and Jogjakarta. Buletin Penelitian Sistem Kesehatan-Vol. 18, 3 Juli 2015 : 221-228

[15] Moehji, Sjahmien. (2003). Ilmu Gizi I: Penanggulangan Gizi Buruk. Jakarta: Papas Sinar Sinanti Bhratara.

[16] Notoatmodjo, S. (2007). Promosi Kesehatan dan Ilmu Perilaku. Jakarta : Rineka Cipta 2007.

[17] Novika, Nuryani \& Hano, Yanti Hz. (2018). Pengetahuan, Asupan Energy dan Zat Gizi Berhubungan dengan Energy Kronis. Gorontalo Journal of Public Health. Volume 1, No. 1, April 2018: 2614-5057.

[18] Rahmaniar, AMB. (2011). Faktor-Faktor Yang Berhubungan Dengan Kekurangan Energi Kronis Pada Ibu Hamil di Tampa Padang Kabupaten Mamuju Sulawesi Barat. Jurnal Ilmiah Media Gizi Masyarakat Indonesia, Vol (2). No (2).

[19] Shaheen R, Lindholm L. (2006). Quality of Life Among Pregnant Women With Chronic Energi Deficiency in Rural Bangladesh. Centre for Health and Population Research Health Policy. Vol:78. Pp: 128-134.

[20]Soekirman. (2000). Ilmu Gizi dan Aplikasinya Untuk Keluarga dan Masyarakat. : Jakarta: Direktorat Jendral Pendidikan Tinggi, Departemen Pendidikan Nasional.

[21] Soetjiningsih, dkk. (2008). Buku Ajar 1, Tumbuh Kembang Anak dan Remaja: Gizi Untuk Tumbuh Kembang Anak, ed 1. Jakarta: Sagung Seto.

[22] Supariasa, Bakin, \& Fajar. (2012). Penilaian Status Gizi Edisi Revisi. Jakarta: Kedokteran ECG.

[23] Wirjatmadi, B. (2014). Peranan Gizi Dalam Siklus Kehidupan. Jakarta : Kencana Prenada Media Group.

[24]Zulkifli, A \& Eva, K. (2014). Faktor-Faktor yang Berhubungan dengan Kepatuhan Ibu Hamil Mengkonsumsi Tablet Fe di Puskesmas Bojonggede Kabupaten Bogor. Skripsi. Fakultas Kedoteran Universitas Swadaya Gunung Jati Cirebon.

\section{PROFIL PENULIS UTAMA}

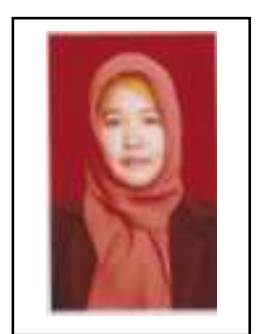

Nama : Cahaya Indah Lestari, S.ST

Riwayat Pendidikan :

D-III Kebidanan Poltekkes Kemenkes

Mataram (2007)

D-IV Kebidanan Poltekkes Kemenkes

Mataram (2011)

Alamat : Mataram, Nusa Tenggara Barat

Penelitian Lain :

Hubungan umur wanita dengan kejadian kanker payudara di Rumah Sakit Umum Propinsi NTB tahun 2013
Gambaran tingkat pengetahuan ibu nifas tentang teknik menyusui yang benar di wilayah kerja Puskesmas Dasan Cermen tahun 2014

Pengaruh penyuluhan teknik pijat bayi terhadap pengetahuan dan keterampilan pijat bayi pada ibu di Dusun Pandanan tahun 2015 